\title{
Spectacled Bears in Peru
}

\author{
Bernard Peyton
}

Land nationalisation, starting in 1963, brought settlers and cultivation into mountain areas of Peru where hitherto spectacled bears had been disturbed only by occasional hunting. This greatly reduced the numbers of bears, and also habituated those that survived to eating the farm crops and farm animals that replaced their natural foods, thus incurring the wrath of the farmers who replied with guns. Moreover, bears are becoming isolated from each other, in some cases confined to high ridges surrounded by cultivated land. The author, who spent two years studying the spectacled bear in Peru, believes that as a result, fewer bears will be able to breed and that genetic variation will be reduced.

In the 1960s several surveys revealed that the spectacled bear Tremarctos ornatus populations had decreased all along the Cordillera Occidental, the western face of the coastal Andean range in Peru, $3,4,8,14$ and that habitat loss and hunting were continuing. The species was given vulnerable status in the IUCN Red Data Book.

Since 1961 Peru has created four parks or sanctuaries - Unidades de Conservación - containing spectacled bears and in 1975 ratified CITES (Convention on International Trade in Endangered Species); Peru also enacted a Forestry Law (no. 21147), which established management guidelines for the newly created Forestry Police to protect the national parks and control hunting. ${ }^{15}$ Nevertheless, an emotional battle has developed between wildlife managers, protectionists, and sport hunters over the status of spectacled bears. Some Peruvians claim that the species has been wiped out, while sport hunters, disregarding the protection laws, hunt them with fair success and claim that there are still many bears in Peru.

To help the Ministerio de Agricultura Departamento de Flora y Fauna gather the necessary data, the author conducted a two-year survey (1977-1979) which included hundreds of interviews with knowledgeable hunters and local farmers and 54 field trips, ranging in altitude from $200 \mathrm{~m}$ to over $5200 \mathrm{~m}$. Thirty-nine of the field trips yielded 739 signs of spectacled bears, in the form of sightings, feeding signs, scats, tracks, day beds, tree nests, and climbing marks. For each of 254 of these signs a $400-\mathrm{sq}-\mathrm{m}$ plot was delineated with the bear sign in the centre, and estimates made on the percentage of vegetation within the plot that provided cover and food, a system effectively used by Jonkel, Mealy and Demarchi to evaluate critical habitat for grizzly bears. ${ }^{7}$ This article examines the results of these estimates along with the effects of human land usage on spectacled bear populations.

\section{History}

The decline in spectacled bear numbers in Peru seems to be closely related to the history of agrarian reform. The Incas and their predecessors, the Chimus (1250-1438 AD), coexisted peacefully with spectacled bears, and the lack of bear representations in their art forms suggests that this shy and largely 


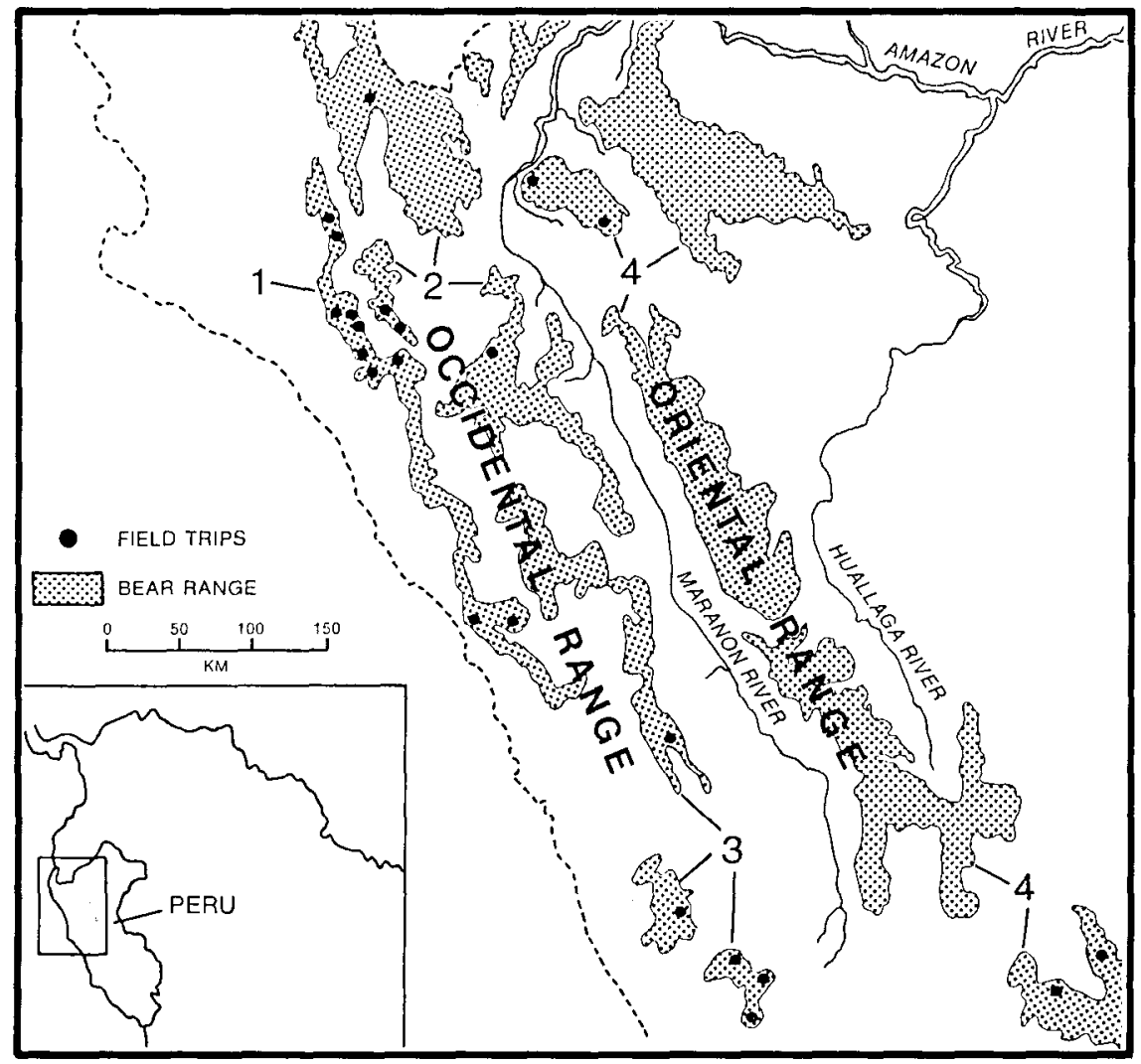

herbivorous animal did not compete with man for food or threaten his survival. The Incas were among the first wildlife managers in the New World, and they responded to predation by pumas Felis concolor incarum on their livestock by huge periodical drives to round them up. Spectacled bears that were caught in these drives were either released or killed for meat; the bear's subcutaneous fat was used as a salve to cure tumours. ${ }^{2}$ These drives continued to the $1840 \mathrm{~s}$, and Tschudi witnessed several drives where bears constituted only a small fraction of the round-up. ${ }^{17}$ In the Oriental Andes bear densities may have been no higher in past than they are now, but in the Occidental Andes they had started to diminish by Tschudi's time.

In the late 18th and 19th centuries the descendants of the Spanish Conquistadores pursued the bears for sport during their seasonal migration to the floodplains of the coastal desert. Hunting on horseback, these mestizo corregidores ran the bears down in the open desert, where there was less than five per cent vegetation cover in which they could hide, lassoed them and clubbed them to death. In the latter half of the 19th century, when the corregimientos became privately owned farms ${ }^{10}$ the owners hunted bears with dogs (Mario Flores, pers. comm.), a practice which continued into the 20th century and extended bear hunting into the arid foothills ${ }^{12}$ and the humid forest of the Occidental Andes. The spectacled bear trees easily when chased by dogs, unlike its close relative, the black bear Ursus americanus. ${ }^{5}$

Twentieth-century hunters, like their predecessors, identified the bears with superhuman strength and virility; similarly the sierra people today feed bear scats to their cattle to make them stronger, and drink the blood of freshly 


\section{Figure 1}

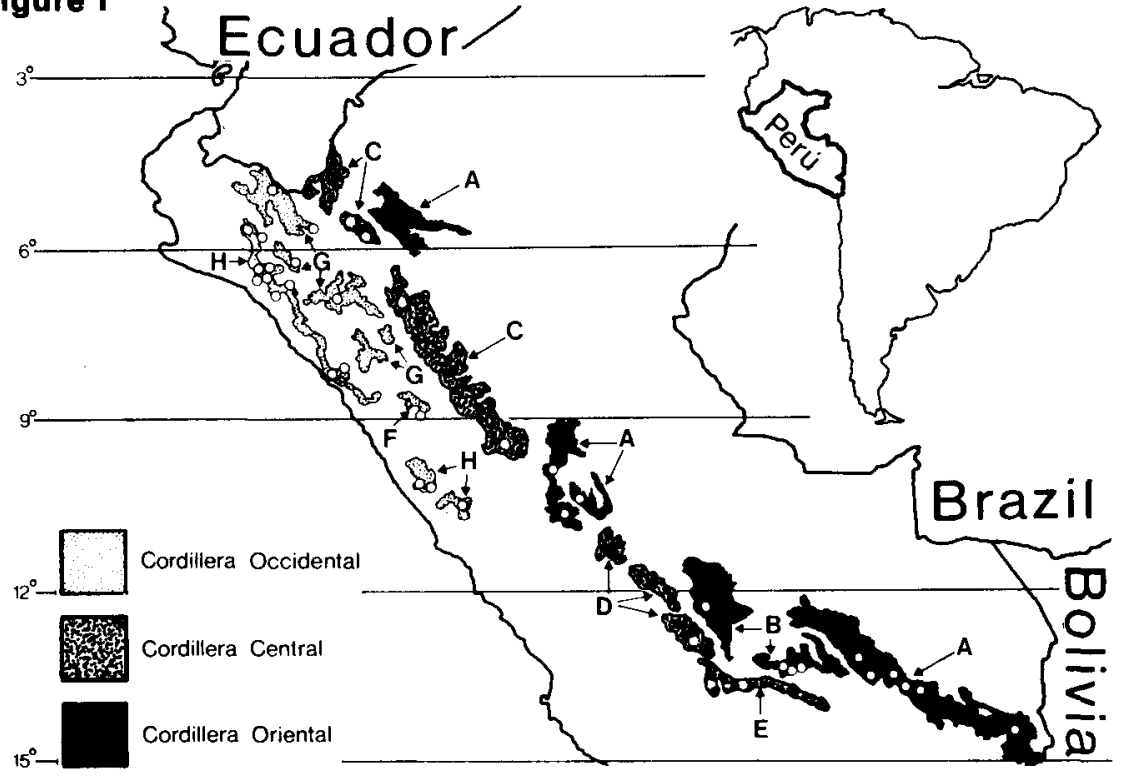

Capital initials A-H in the text refer to those on the map above and the figure below

\section{Figure 2}

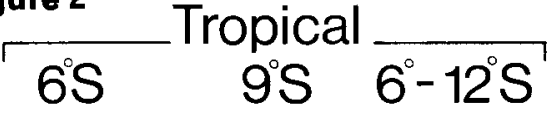

Subtropical

$$
13^{\circ}-13.5^{\circ} \mathrm{S}
$$

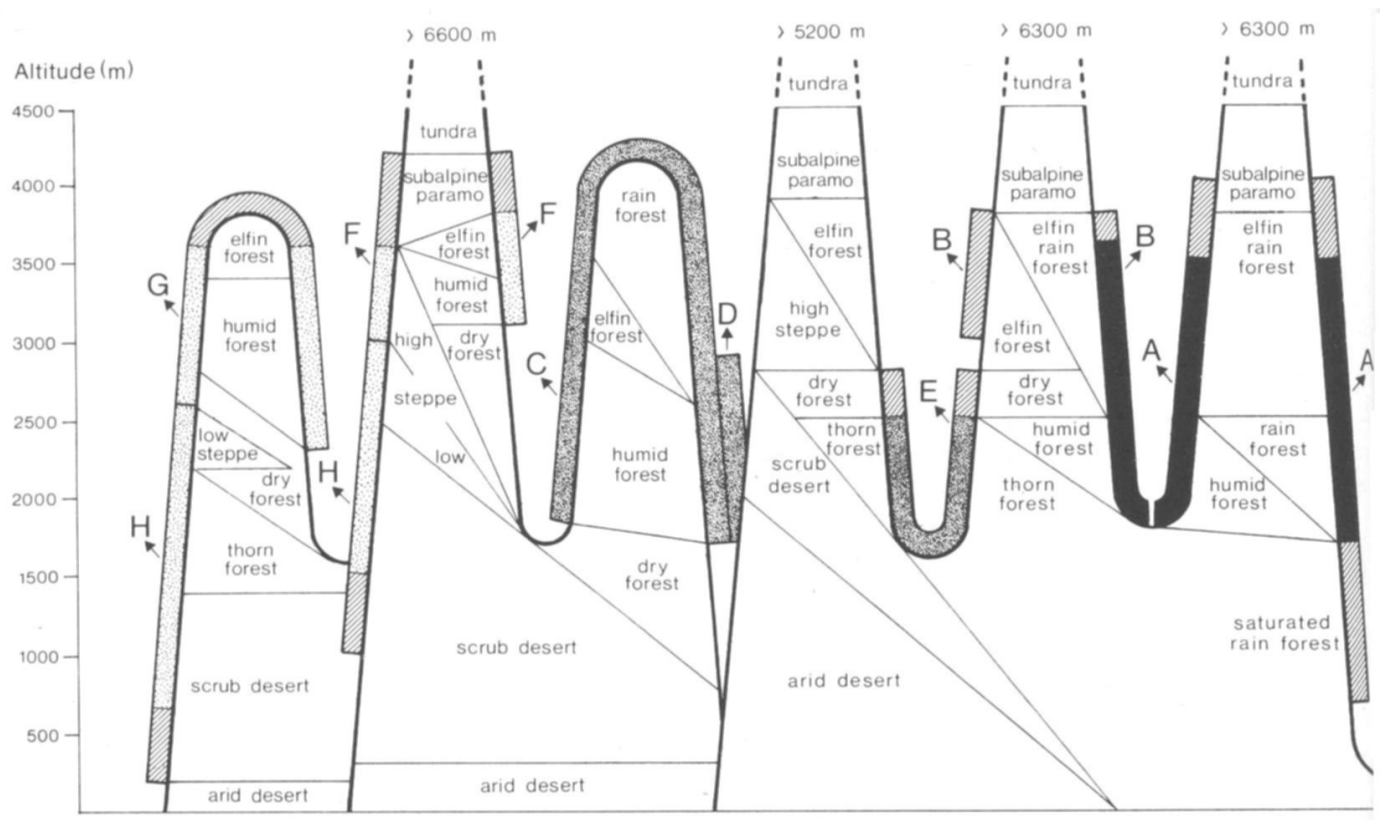


killed bears as a sort of communion to help them become more bearlike. In Peruvian markets one can usually find bear fat on sale as a salve for bruises, claws sold as charms, and baculum bones as aphrodisiacs.

Although hunter-landowners were largely responsible for the decrease in bears in parts of the coastal desert and along the Pampas and Apurimac Rivers, they also preserved bear habitat by maintaining strict control over their tenant farmers. Under the Agrarian Reform policy of General Fernando Belaunde Terry (1963-1968) the State acquired 86.3 per cent of Peru's land, ${ }^{18}$ most of it Amazonian wilderness which Belaunde dreamed of developing, and roads into the jungle opened up bear habitats in the Central and Oriental Andes to agriculture and logging. After the 1968 military coup, General Juan Velasco Alvarado's government extended State ownership to include practically all the large privately owned farms, and more than eight million acres ${ }^{10}$ were turned into cooperative farms.

By 1975 food production had fallen to $30-50$ per cent of what it had been in $1970,{ }^{18}$ and a rising population soon exceeded the carrying capacity of the cooperative farms. Lacking the controls of the former hacienda owners, people cut down forests indiscriminately and moved into bear-inhabited areas. The result for the bears was a reduction of their habitat, isolation from food sources and from each other, and increasing habituation to eating man's crops and livestock as these foods replaced their natural foods. Local farmers respond to crop raids by enlisting hunters to wait in their fields and shoot the bears as they come out to feed. Cornfields have become to the modern hunter what the desert floodplains were to the descendants of the Spaniards.

\section{Range}

Spectacled bears inhabit the Andean Range from the Cordillera de Merida in western Venezuela to Bolivia; the largest populations are reported to be in isolated areas of Ecuador, ${ }^{4}$ southern Colombia, and scattered areas of Peru. ${ }^{1,}{ }^{6},{ }^{13}$ In Peru they are found in all three ranges of the Andes, but mostly in the humid forest habitat on the eastern face of the Cordillera Oriental, known as the ceja de selva. Apart from the slopes on both banks of the Pampas, Apurimac, and Santo Thomas Rivers (E), they are absent from the foothills below $1800 \mathrm{~m}$ of all the major waterways between the three Andean Ranges. They are also absent south of $13^{\circ} 43^{\prime}$ in both the Cordillera Central and the western aspect of the Cordillera Oriental, the Carabaya Range, and south of the Pativilca River $\left(10^{\circ} 42^{\prime} \mathrm{S}\right)$ in the Occidental Range.

\section{Habitat}

The most impressive feature of spectacled bear ecology is the animal's ability to adapt to a wide variety of habitat types. Bear signs were seen on this survey at elevations as low as $200 \mathrm{~m}$ and as high as $4170 \mathrm{~m}$. Humid forests and thorn forests offer the most food and hiding cover, as the plot study showed, but only the inaccessible populations in the ceja de selva enjoy security from man.

Most of the bear areas in the scrub desert and adjacent thorn forest habitats of the western aspect of the Cordillera Occidental (H) cover less than $450 \mathrm{sq}$ $\mathrm{km}$. They occur in the form of narrow bands roughly following the contours and spanning between 200 and $1000 \mathrm{~m}$ in altitude. The populations are separated from each other by human settlements along the roads and rivers from the highlands to the coast, and by settlements sandwiched between bands 
or above bands, where the annual rainfall exceeds $500 \mathrm{~mm}$. These bears would certainly have disappeared if their home ranges were not centred around steep cliffs and deep V-shaped ravines. The cliffs deter both humans and their livestock: they also shade water holes, which normally evaporate after the rainy season (December-February) in unprotected areas, and provide up to a $25 \mathrm{per}$ cent cover of Bromeliaceae, which constitutes the bulk of the spectacled bear's diet at times when there is no fruit on the cacti, trees and shrubs. ${ }^{13}$ The ravines provide the spectacled bear with day bedding sites near water holes, fruit-bearing trees which they climb to feed (Ficus spp., Inga feuillei, and Lucuma sp.) and protective cover for their descent in February-March to the desert floodplains, where they eat the fruits of Capparis angulata and C.ovalifolia.$^{13}$ Coastal hunters told me that, prior to the Agrarian Reform years, they regularly shot bears at this time, often seeing as many as six to nine in a single day. One hunter in Trujillo showed me photographs of 27 of the more than 100 bears he claims to have shot during these food migration periods. Like most hunters of the coast he has not seen a bear for 15 years.

Hunters are not solely responsible for the decline in bear numbers along the coast. Small private timber companies and the coastal herdsmen are cutting down the principal indicator species of the scrub desert and thorn forest to provide boxes for lemons (Bursea graveolens), charcoal and building (Prosopis limensis and Bombax discolor), flooring (Loxopterygium huasango) and firewood. (The logging near Olmos, in ravines between 350 and $1000 \mathrm{~m}$, may mean the eventual extinction of the endemic white-winged guan Penelope albipennis.) Bears in this area north to the town of Canchaque are now highly habituated to eating corn and livestock. In dry areas with less than $200 \mathrm{~mm}$ of annual precipitation stock grazing and the elimination of vegetation have prevented bears from moving to the food sources in the low desert and also moving between sub-populations. There are probably fewer than 100 bears in the coastal scrub desert and thorn forest, most of them isolated on ridgetops surrounded by heavily used and altered land.

A small population of spectacled bears inhabits the thorn forest along the Santo Thomas, Apurimac, and Pampas Rivers from the town of Ocros to Chulpi, where steep slopes of often more than $50^{\circ}$ and unnavigable rivers prevent both hunters and grazing animals from entering. The small quantity of fruit in this thorn forest may account for the difference in size between these bears (weighing up to $35 \mathrm{~kg}$ ) and those of the coastal thorn forest (up to 200kg), but more work needs to be done to determine whether there is a genetic reason. In February, the bears climb to the more moderate slopes above the cliffs $(2800-2900 \mathrm{~m})$ to feed on one of the few fruits, the cactus Opuntia ficus. ${ }^{13}$ Hunters of Ocros, Andahuaylus, Chincheros, and Abancay claim that, prior to the Agrarian Reform years, it was possible to see up to nine bears feeding together in the Opuntia groves where today cattle are grazing and people are collecting the fruit and the cochineal worm that is found on the cactus. Erosion is now the major problem here. Villagers collect four mule-loads of lumber twice a week, often travelling four hours to a suitable supply. As the forest is removed and the ground trampled by livestock, more habitat will be lost.

Spectacled bears still survive in low numbers in the steppe lands and subalpine paramo along the northern boundary of Huascaran National Park (F) where grasslands predominate and cover for bears is under one per cent. Bromeliad cover, which can be substantial ( 60 per cent) in the rocky areas of 


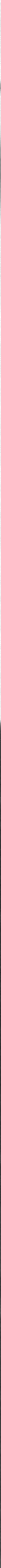


the steppe, is often burned off by herdsmen. Livestock also take over the valley floors and so deprive the bears of the best feeding areas for the small supply of fruits (1-3 per cent coverage) such as Schinus molle and Opuntia ficus. ${ }^{13}$ In the subalpine paramo, bromeliad cover is scant and the pockets of Polylepis incana and Buddleia coriacea, which regenerate slowly, are being removed for firewood. Herdsmen and miners, who make use of the park up to $4400 \mathrm{~m}$, told the author that bears centre their home ranges on the inaccessible valleys north of the park boundary (Quebrada Quitaracsa - Nev. Alpamayo) and only venture into the park in the rainy season, October to February, when local people and tourists avoid the highlands. After the earthquake of 1970, which left more than one million people homeless in this part of the sierra, bears along with other animals are said to have almost disappeared.

The subalpine areas of southern Peru (A,B) are similarly used by people, but here the subalpine habitat is not separated from the humid forest by large settlements, and the slightly higher coverage of fruit-bearing trees and Ericaceae in the southern paramo attracts bears to the highlands between February and April. The highlands of Manú National Park are representative of this ecological zone and, like much of the southern paramo, full of livestock. Where cattle were present, bear sign was found within one metre of cover or a steep slope that offered an escape route, but where there were no cattle or sign of them, the bear sign indicated that the animal moved freely away from cover. ${ }^{13}$ The presence of cattle has also led some bears to prey on livestock.

The best bear habitat is the humid forest between 1800 and $2700 \mathrm{~m}$ with an annual precipitation ranging from 1800 to $3000 \mathrm{~mm}$ (A,B,C,D and $G$ ). These climatic conditions occur in about 1.14 per cent of Peru's land mass, but most of the climax forest has been replaced by Pinus radiata and Eucalyptus $\mathrm{spp},{ }^{11}$ or by crops of maize Zea mays, Solanum andiginum, Oxalis tuberosa, manioc Manihot esculenta, Capsicum pubescens, Arabian coffee Coffea arabica, tea Thea sinensis, and Erythroxilum coca (source of cocaine). The forests with the most food for bears are on moderate slopes (up to $15^{\circ}$ ), with trees up to $30 \mathrm{~m}$ covered with epiphytic bear foods such as Tillandsia spp. and orchid bulbs. Twenty-one tree species showed signs of repeated climbing over the years, suggesting that spectacled bears may centre their home ranges around known groves of trees. ${ }^{14}$ Hunters using dogs reported fair success in treeing bears, particularly in the fruiting season of Cecropia sp., Eugenia sp., Ficus spp., Benchesia sp., and Sideroxylon sp. ${ }^{13}$

Most hunting in the last 30 years has been by the military and contract hunters accompanying the road crews, and they have hunted for spectacled bears, the endemic yellow-tailed woolly monkey Lagothrix flavicauda and, most devastatingly, the taruka (huemul) Hippocamelus antisensis (pers. obs.), ${ }^{8}$ prized trophy for sport hunters and often shot by irritated local farmers for its habit of eating potato leaves. There are good taruka populations in the Departments of Cuzco, Puno, and Arequipa, but the animal is specific to the drier regions of the paramo which is increasingly used by herdsmen.

Bears habituated to crop feeding were particularly abundant in the eastern aspect of the Cordillera Central (D), and in the ceja de selva of the Cordillera Oriental south of $12^{\circ} \mathrm{S}$. Of the 25 raided cornfields examined here, five had been half-eaten and three totally, the latter representing about half the owner's annual food production. ${ }^{13}$ Villagers would send crop guards to deter them by burning rubber where the bear trails entered the cornfields, lighting fires and 
erecting flags. Twice the author saw a feeding bear ignore all these efforts and put up with 20 minutes of yelling from the crop guards 40 metres away. ${ }^{13} \mathrm{Cubs}$ learn this behaviour and are said to be the most often shot in cornfields.

The bears make little use of the elfin rain forest*, where the characteristic steep slopes often exceed $70^{\circ}$ and the annual precipitation ranges from 2000 to over $4000 \mathrm{~mm}$. Chusquea spp. and Guadua sp. dominate the slope vegetation (80-90 per cent coverage) with intermittent groves of stunted trees of Podocarpus sp., Alnus sp., Berberis sp., Baccharis sp., and Weinmannia spp. ${ }^{13}$ The forests here showed the least human use of any of the bear habitats in Peru, and thus offered the most seclusion, yet only four per cent of the signs were found in it, perhaps because the spectacled bear prefers the foods and more open ground above and below the Chusquea forest. In the 22 areas where these forests were found $(A, B, C, D$ and $G$ ) bears had their own trails running through dense vegetation on ridge lines that connected the humid forest with the open grasslands above the elfin forest, at $3200-3500 \mathrm{~m}$. As in the paramo habitats, livestock grazing increases every year in these humid grasslands, and in cattle areas the bear sign showed the same pattern of being close to cover. Because the high humidity and low temperatures make this a poor grazing area, and the steep slopes aid erosion, the ONERN office has judged this a poor human-use zone that should be protected. ${ }^{11}$

\section{Conservation}

The Huascaran and Cutervo National Parks and the newly created Historical Sanctuary of Machu Picchu are too small to preserve spectacled bears effectively. Species on the top trophic rung using diverse food sources need large amounts of space, and since spectacled bears are able to use extreme habitat types, the siting of the parks is less important than their size and management. ${ }^{18}$ The best conservation measure for the spectacled bears would be to make buffer zones surrounding the parks and integrate them into the park management plans. The area immediately adjacent to the north-east boundary of the Machu Picchu Historical Sanctuary, for example, contains humid forests that are best suited to the bear's ecological needs, has a good population of bears, a remnant population of taruka and fairly good populations of Pudu mephistophles, brocket deer Mazama chunyi, and $M$. americana. Laws should be enforced which prevent indiscriminate logging, forest burning, and grazing in protected areas. Particular attention should be paid to managing areas where the bear's preferred foods grow, for, in all the bear habitats, local people report that between February and July boars accompany sows at these sites, sometimes with yearling cubs, so they may also serve the purpose of bring potential mating pairs together.

Funds are needed to provide the Tingo Maria and Cutervo National Parks with boundaries and also the Forestry Police with biologists trained in wildlife management and field methods. A limited harvest of spectacled bears by licensed hunters would not directly benefit the species at this time, and chemical, shock-producing or noise devices that have been developed to control problem bears are unlikely to succeed in the Andes because they are too costly, depend on energy sources, and are likely to be mistrusted by local farmers.

*Elfin forest, or Krummholz: scrubby stunted trees making a characteristic zone at the upper limit of tree growth in mountains. 


\section{Acknowledgments}

The author would like to thank the New York Zoological Society for providing partial funding for this survey and Dr Marc Dourojeanni Ricordi, Director General of Fauna y de Flora, Dr Carlos Ponce del Prado, Sub Director de Conservacion de la Fauna Silvestre, and especially Dr Antonio Brack Egg, Director del Proyecto Vicuña, for their assistance and cooperation throughout the study. Special thanks to to Dr Albert W. Erickson and D. Charles J. Jonkel for training before the study began and to Edgar Muñiz Luna, Gustavo del Solar, Renato Marin, and Ismael Noya de la Piedra and their families for housing and assistance. Lastly, for their help in the field, the author would like to thank Mariella Leo, Roberto Rodriguez, Enrique Ortiz, Jennifer Pennoyer, Robert Olney, Susanne Tilney, Daniel Bejar, Melanio Condores, Bernaber Flores, Daniel Quispe, Daniel la Torre and Manuel Sanchez.

\section{References}

1. ALLEN, G.M. 1942. Extinct and vanishing mammals of the western hemisphere. Spec. Publ. no. 11, Amer. Comm. for Int. Wildl. Prot.: 396-400. 620 pp.

2. BAUMANN, H. 1963. Gold and Gods of Peru. Pantheon Books, New York: 81. $218 \mathrm{pp}$.

3. BRACK EGG, A. 1961. El oso de anteojos. Biota. 3: 345-50.

4. ERICKSON, A.W. 1966. Spectacled bear - status survey in South America. Ark Under Way, 2nd report to WWF 1965-67: 206-207.

5 .ERICKSON, A.W. 1966. Preliminary report of investigations on the status of the Andean spectacled bear (Tremarctos ornatus). Unpubl. progress report for the World Wildlife Fund project 187.17 pp.

6. GRIMWOOD, I.R. 1969. Notes on the distribution and status of some Peruvian mammals. Amer. Comm. for Int. Wild. Prot. and N.Y.Zool.Soc. Spec. Publ. 21:1-86.

7. MEALY, S.P., C.J. JONKEL and R. DEMARCHI 1977. Habitat criteria for grizzly bear management. XIIIth Congress of Game Biologists, Grizzly Habitat Research, Atlanta, Georgia: 276-289.

8. MEALY, S.P., C.J. JONKEL and R. DEMARCHI 1974. Red Data Book, IUCN, Switzerland.

9. MITTERMEIER, R.A., H. de Macedo Ruiz, and A. Luscombe. 1975. A woolly monkey rediscovery in Peru. Oryx., 14: 44.

10. .MARTIN, L. 1974. The Kingdom of the Sun. Charles Scribner's Sons, New York.

11. ONERN 1976. Mapa ecologico del Perú. Oficina Nacional de Evaluacion de Recursos Naturales, Lima: 99, 103, 128.

12. OSGOOD, W.H. 1914. Mammals of an expedition across northern Perú. Field Mus. Nat. Hist. Publ., Zool. Ser., 10: 143-185.

13. PEYTON, B. 1980. Distribution and Food Habits of the spectacled bear, Tremarctos ornatus, in Perú. F. of Mamm. 6: 639-652.

14. PIERRET, P.V. 1966. La fauna del norte del Perú, situacion actual y porvenir. Unpubl. report to the Servicio Forestal y de Caza, Lima, Perú, 14 pp.

15. DOUROJEANNI, M.J., and C.R. PONCE 1978. Los parques nacionales del Perú. Instituto de la Caza Fotografica y Cienas del la Naturaleza, Madrid: 12-19.

16. TERBOROGH, J. Preservation of natural diversity: the problem of extinctionprone species.

17. TSCHUDI, J.J.von. 1844. Therologie. In, Untersuchungen ueber die fauna peruana, St. Gallen: $1-262$.

18. TUESTA, A.B. 1977. El poder invisible. Editorial Andina, S.A., Lima: 214 348-9.

New York Zoological Society, Bronx Zoo, Bronx, NY 10460. 